\title{
BUDAYA RELIGIUS DALAM MENINGKATKAN PROFESIONALISME DOSEN PENDIDIKAN AGAMA ISLAM FITK UIN MALIKI MALANG
}

\author{
Misbah Munir \\ Fakultas Ilmu Tarbiyah dan Keguruan Universitas Islam \\ Negeri Maulana Malik Ibrahim Malang \\ Email: misbahchasbullah@gmail.com
}

\begin{abstract}
The institution is now faced with the challenges of globalization and the increased flow of technology very quickly. This phenomenon became the motivation for educational institutions to continue to learn and improve to work more professional in his field. The institution also responds to the presence of the desire of the community to the services of quality education, to be realized it can be done through a process of planned, terpola, and tersistematisasi through an educational process that leads to the realm of cognitive, affective, psychomotor. In addition, it can also be done through establishing a conducive campus culture through the creation of religious culture on campus, through activities such as the obligatory prayers in congregation activities, recite the Koran, do prayers together, the process of teaching started by reading al-fatiha and continued with reading Koran together, after it finishes with reading hamdalah together and use a neat muslim muslimah clothing at work.
\end{abstract}

Keywords: Cultural, Religious, FITK UIN Maliki Malang

\begin{abstract}
Abstrak: Lembaga pendidikan sekarang ini dihadapkan pada tantangan arus globalisasi dan peningkatan teknologi yang sangat cepat. Fenomena ini menjadi motivasi bagi lembaga pendidikan untuk terus belajar dan meningkatkan kemampuan untuk bekerja lebih profesional di bidangnya masing-masing. Lembaga pendidikan juga merespon adanya keinginan masyarakat terhadap layanan pendidikan yang bermutu, untuk diwujudkan hal itu dapat dilakukan melalui proses yang terpola, terencana, dan tersistematisasi melalui sebuah proses pendidikan yang mengarah pada ranah kognitif, afektif, psikomotorik. Selain itu, juga dapat dilakukan melalui membangun kultur kampus yang kondusif melalui penciptaan budaya religius di kampus, yaitu melalui kegiatan-kegiatan seperti kegiatan wajib sholat berjamaah, khotmil qur`an, melakukan do`a bersama, proses pengajaran yang dimulai dengan membaca al-fatihah dan dilanjutkan dengan membaca al-Qur'an bersama-sama, setelah itu diakhiri dengan membaca hamdalah bersama-sama dan menggunakan pakaian muslim muslimah yang rapi pada jam kerja.
\end{abstract}

Kata-kata kunci : Budaya, Religius, FITK UIN Maliki Malang

J-PAI : Jurnal Pendidikan Agama Islam

Vol. 4 No. 1 Juli-Desember 2017

Homepage: http://ejournal.uin-malang.ac.id/index.php/jpai/ 


\section{Pendahuluan}

Keberadaan lembaga saat ini dihadapkan pada pada arus globalisasi dan perkembangan ilmu pengetahuan dan teknologi yang makin cepat. Teknologi telah memberikan banyak kemudahan, serta sebagai cara baru dalam melakukan aktivitas manusia. Manusia juga sudah menikmati banyak manfaat yang dibawa oleh inovasi-inovasi teknologi yang telah dihasilkan dalam dekade terakhir ini. Pada satu sisi, perkembangan dunia IPTEK yang demikian mengagumkan itu memang telah membawa manfaat yang luar biasa bagi kemajuan peradaban umat manusia. kemajuan teknologi saat ini benar-benar telah diakui dan dirasakan memberikan banyak kemudahan dan kenyamanan bagi kehidupan umat manusia.

Di sisi lain, manusia tidak bisa menipu diri sendiri akan kenyataan bahwa teknologi juga mendatangkan dampak negative. Contohnya penemuan televisi, komputer, internet, dan handphone telah me-ngakibatkan kita terlena dengan dunia layar. Layar kemudian menjadi teman setia, bahkan kita lebih memperhatikan dunia layar diban-dingkan istri/suami, dan anak sekalipun. Secara sosiologis teknologi memiliki makna yang lebih mendalam daripada peralatan. Teknologi menetapkan suatu kerangka bagi kebudayaan non material suatu kelompok. Jika teknologi suatu kelompok mengalami perubahan, maka cara berpikir manusia juga akan mengalami perubahan. Hal ini juga berdampak pada cara mereka berhubungan dengan yang lain.

Pandangan ini telah menjadikan motivasi tersendiri bagi lembaga pendidikan masing-masing untuk terus meningkatkan mutu pendidikan terutamanya dalam bidang manajemen pendidikan yang akuntabel, transparan dan akomodatif terhadap perubahan zaman. Hal ini akan memicu iklim persaingan yang sehat antar lembaga pendidikan di berbagai wilayah untuk selalu meningkatkan kinerja tenaga kependidikan yang pada akhirnya akan menemukan sebuah strategi peningkatan kinerjanya. Kondisi ini mengandung makna bahwa ini merupakan tantangan dan tuntutan bagi tenaga kependidikan masing-masing untuk terus belajar dan meningkatkan kemampuan diri untuk bekerja lebih profesional di bidangnya masingmasing.

Dalam upaya menjawab tuntutan dan tantangan di atas lembaga pendidikan dituntut untuk mampu melengkapi lulusannya agar memiliki keterampilan teknis (hard skill), dan juga kemampuan untuk berpikir analitis, berkomunikasi, serta bekerjasama dalam tim yang secara keseluruhan sering dirangkum sebagai keterampilan lunak (soft skill), maka lembaga pendidikan sekarang dituntut utuk mampu memberikan keluaran pendidikan yang berkualitas yaitu kualitas 
manusia yang dibutuhkan oleh bangsa Indonesia pada masa yang akan datang yaitu manusia yang mampu menghadapi persaingan yang semakin ketat dengan bangsa lain di dunia. Kualitas manusia tersebut mampu dihasilkan melalui penyelenggaraan pendidikan yang bermutu. Proses pendidikaan yang di maksud adalah pendidikan yang mampu memberikan pemahaman dan mampu diinternalisasikan dalam diri dan diwujudkan dalam prilakunya, artinya pendidikan yang dimaksud adalah pendidikan yang mampu memberikan pembelajaran mengarah pada ranah pendidikan (yaitu kognitif, afektif, psikomotorik).

Berpijak pada realitas yang ada, pendidikan Agama Islam sebagai salah satu kegiatan untuk membangun kekuatan imtaq yang kokoh dalam diri mahasiswa, tentu diharapakan mampu berperan secara maksimal. Artinya pendidikan Agama Islam tidak hanya menstranfer keilmuan saja, akan tetapi diharapkan pendidikan Agama Islam mampu menstranfer nilai-nilai yang terkandung di dalamnya kepada diri mahasiswa. Karena pendidikan Agama saat ini dirasa masih kurang dalam mencapai tujuannya dalam menginternalisasikan nilai-nilai Islam tersebut ke dalam diri mahasiswa. Upaya internalisasi dan perwujudan nilai-nilai keagamaan tersebut perlu dilakukan secara serius melalui suatu program yang terencana. Upaya tersebut tidak semata-mata menjadi dosen agama saja tetapi menjadi tugas dan tanggung jawab kita bersama, terutama pimpinan lembaga pendidikan, bagaimana dapat membangun kultur sekolah yang kondusif melalui penciptaan budaya religius di kampus.

\section{Budaya Religius}

Raymond Williams menyatakan bahwa istilah budaya sebagai "culture" yang berasal dari kata latin colere yang berarti mengolah, mengerjakan dan terutama berhubungan dengan pengolahan tanah, memiliki yang sama dengan kebudayaan. Arti culture berkembang sebagai segala daya dan usaha manusia untuk mengubah alam. Jika diingat sebagai konsep kebudayaan adalah keseluruhan gagasan dan karya manusia, yang harus dibiasakannya dengan belajar beserta keseluruhan dari hasil budi dan karya. Dalam kamus Inggris-Inggris, Oxford, "culture" diartikan sebagai kebudayaan yang berarti perkembangan pemikiran (mind) dan kerohanian (spirit) sekelompok manusia melalui latihan dan pengalaman. Sedangkan menurut Kamus Besar Bahasa Indonesia, kebudayaan adalah keseluruhan pengetahuan manusia sebagai makhluk sosial yang digunakan untuk memahami lingkungan serta pengalamannya dan yang menjadi pedoman tingkah laku manusia (Ujan, 2009, 22).

Dengan semua unsur tersebut maka budaya dipandang sebagai 
totalitas perilaku, kesenian, kepercayaan, kelembagaan, dan semua produk lain karya pemikiran manusia yang mencirikan suatu masyarakat atau produk yang ditransmisikan bersama. Sedangkan kebudayaan adalah pengetahuan yang dimiliki manusia dalam proses untuk menginterpretasikan dunianya sehingga manusia dapat menghasilkan tingkah laku tertentu.

Secara bahasa ada tiga istilah yang masing-masing kata tersebut memiliki perbedaan makna, religi, religius, religiusitas, dan religious. Religi berasal dari kata religion sebagai bentuk dari kata benda yang berarti agama atau kepercayaan akan adanya sesuatu kekuatan kodrati di atas manusia. Religusitas berasal dari kata religious yang berkenaan dengan religi atau sifat religi yang melekat pada diri seseorang. Pengertian agama menurut Glock dan Stark adalah simbul system keyakinan, system nilai, dan system prilaku yang terlembagakan, yang semuanya itu berpusat pada persoalan-persoalan yang dihayati sebagai yang paling maknawi

\section{Budaya Kampus}

Budaya kampus (campus culture) merupakan aplikasi budaya organisasi terhadap eksistensi kampus. Kampus, sebagai organisasi yang bergerak di bidang pendidikan seharusnya memiliki budaya yang menunjukkan kapabilitas yang sesuai dengan tuntutan pendidikan dan pembelajaran tersebut, terutama menumbuhkembangkan mahasiswa sesuai dengan prinsip-prinsip kemanusiaan (Komariah, Triatna, 2006, 101) baik saat di ruang kelas hingga di lingkungan sekolah secara keseluruhan. Budaya merupakan salah satu faktor penting dalam upaya reformasi atau perbaikan mutu lulusan.

Muhaimin $(2009,312)$ mendefinisikan budaya agama (dalam konteks pendidikan) sebagai suatu usaha sadar dan terencana untuk mewujudkan lingkungan dan secara aktif mengembangkan potensi dirinya untuk memiliki kekuatan spiritual keagamaan yang berakar dari nilai-nilai agama dan mengamalkannya sebagai basis dasar kehidupan sehari-hari.

\section{Penanaman Nilai-Nilai Religius}

Istilah nilai keberagamaan (religius) merupakan hal yang tidak mudah untuk diberikan batasan secara pasti. karena nilai-nilai dalam yang terkandung dalam agama merupakan sebuah realitas yang abstrak. nilai merupakan suatu tipe kepercayaan yang berada pada suatu lingkup sistem kepercayaan di mana seseorang bertindak untuk menghindari suatu tindakan, atau mengenai sesuatu yang dianggap pantas atau tidak pantas. Ini berarti pemaknaan atau pemberian arti 
terhadap suatu objek. Sedangkan keberagamaan merupakan suatu sikap atau kesadaran yang muncul yang didasarkan atas keyakinan atau kepercayaan seseorang terhadap suatu agama. Menurut Nurcholis Madjid agama bukanlah sekedar tindakan-tindakan ritual seperti shalat dan membaca do'a. Agama lebih dari itu, yaitu keseluruhan tingkah laku manusia yang terpuji, yang dilakukan demi memperoleh ridla atau perkenan Allah. Agama dengan demikian meliputi keseluruhan tingkah laku manusia dalam hidup ini, yang tingkah laku itu membentuk keutuhan manusia berbudi luhur atas dasar percaya atau iman kepada Allah dan tanggung jawab pribadi di hari kemudian.

Bila nilai-nilai religius tersebut telah tertanam pada diri mahasiswa dan dipupuk dengan baik, maka dengan sendirinya akan tumbuh menjadi jiwa agama. Dalam hal ini jiwa agama merupakan suatu kekuatan batin, daya dan kesanggupan dalam jasad manusia yang menurut para ahli Ilmu Jiwa Agama, kekuatan tersebut bersarang pada akal, kemauan dan perasaan. Selanjutnya, jiwa tersebut dituntun dan dibimbing oleh peraturan atau undang-undang Ilahi yang disampaikan melalui para Nabi dan Rosul-Nya untuk mengatur hidup dan kehidupan manusia. Bila jiwa agama telah tumbuh dengan subur dalam diri mahasiswa, maka tugas pendidik selanjutnya adalah menjadikan nilai-nilai agama sebagai sikap beragama mahasiswa. Sikap keberagamaan merupakan suatu keadaan yang ada dalam diri seseorang yang mendorongnya untuk bertingkah laku sesuai dengan kadar ketaatannya kepada agama. Sikap keagamaan tersebut karena adanya konsistensi antara kepercayaan terhadap agama sebagai unsur kognitif, perasaan terhadap agama sebagai unsur afektif dan perilaku terhadap agama sebagai unsur konatif/ psikomotorik. Jadi sikap keagamaan pada anak sangat berhubungan erat dengan gejala kejiwaan anak yang terdiri dari tiga aspek tersebut.

Dari sekian banyak nilai yang terkandung dalam sumber ajaran Islam, nilai yang fundamental adalah nilai tauhid. Ismail Raji al-Faruqi, menformulasikan bahwa kerangka Islam berarti memuat teori-teori, metode, prinsip dan tujuan tunduk pada esensi Islam yaitu Tauhid. Berkaitan dengan hal tersebut, budaya religius merupakan cara berfikir dan cara bertindak yang didasarkan atas nilai-nilai religius (keberagamaan). Religius menurut Islam adalah menjalankan ajaran agama secara menyeluruh.

Dari uraian di atas dapat dipahami bahwa nilai religius adalah nilai-nilai kehidupan yang mencerminkan tumbuh-kembangnya kehidupan beragama yang terdiri dari tiga unsur pokok yaitu aqidah, ibadah dan akhlak yang menjadi pedoman perilaku sesuai dengan aturan-aturan Ilahi untuk mencapai kesejahteraan serta kebahagian 
hidup di dunia dan akhirat.

\section{Penciptaan Suasana Religius.}

Menurut Muhaimin, penciptaan suasana religius sangat dipengaruhi oleh situasi dan kondisi tempat model itu akan diterapkan beserta penerapan nilai yang mendasarinya.

Pertama, penciptaan budaya religius yang bersifat vertikal dapat diwujudkan dalam bentuk meningkatkan hubungan dengan Allah swt melalui peningkatan secara kuantitas maupun kualitas kegiatan-kegiatan keagamaan yang bersifat ubudiyah, seperti: shalat berjama'ah, puasa Senin-Kamis, khatm al-Qur'an, do'a bersama dan lain-lain.

Kedua, penciptaan budaya religius yang bersifat horizontal yaitu lebih mendudukkan kampus sebagai institusi sosial religius, yang jika dilihat dari struktur hubungan antar manusianya, dapat diklasifikasikan ke dalam tiga hubungan yaitu: (1) hubungan atasanbawahan, (2) hubungan profesional, (3) hubungan sederajat atau sukarela yang didasarkan pada nilai-nilai religius, seperti: persaudaraan, kedermawanan, kejujuran, saling menghormati dan sebagainya (Muhaimin, 2009, 61-62). Pengembangan PAI dalam mewujudkan budaya religius yang bersifat horizontal tersebut dapat dilakukan melalui pendekatan pembiasaan, keteladanan dan pendekatan persuasif atau mengajak kepada warga dengan cara yang halus, dengan memberikan alasan dan prospek baik yang bisa meyakinkan mereka. Sikap kegiatannya bisa pula berupa antisipasi, yakni tindakan aktif menciptakan situasi dan kondisi ideal agar tercapai tujuan idealnya (Muhaimin, 2009, 63-64).

Secara lebih terperinci, strategi pengembangan PAI dalam mewujudkan budaya religius menurut Muhaimin dapat dilakukan melalui empat pendekatan,yaitu:

Pertama, pendekatan struktural, yaitu strategi pengembangan PAI dalam mewujudkan budaya religius sudah menjadi komitmen dan kebijakan pimpinan, sehingga lahirnya berbagai peraturan atau kebijakan yang mendukung terhadap lahirnya berbagai kegiatan keagamaan di kampus beserta berbagai sarana dan prasarana pendukungnya termasuk dari sisi pembiayaan. Dengan demikian pendekatan ini lebih bersifat "top down" yakni kegiatan keagamaan yang dibuat atas prakarsa atau instruksi dari pejabat atau pimpinan kampus.

Kedua, pendekatan formal, yaitu strategi pengembangan PAI dalam mewujudkan budaya religius dilakukan melalui pengoptimalan kegiatan belajar mengajar (KBM) pada mata pelajaran PAI di sekolah 
yang setiap minggu untuk sekolah negeri ditetapkan dua jam pelajaran. Dengan demikian, dalam pendekatan formal ini, dosen PAI mempunyai peran yang lebih banyak dibanding guru mata pelajaran yang lain. Karena bagaimana meningkatkan kualitas mutu pembelajaran PAI di kelas sepenuhnya merupakan tanggung jawab gurru PAI termasuk kegiatan ko-kurikuler pendukungnya.

Ketiga, pendekatan mekanik, yaitu strategi pengembangan PAI dalam mewujudkan budaya religius yang didasari oleh pemahaman bahwa kehidupan terdiri atas berbagai aspek, dan pendidikan dipandang sebagai penanaman dan pengembangan seperangkat nilai kehidupan, yang masing-masing bergerak dan berjalan menurut fungsinya. Masing-masing gerak bagaikan sebuah mesin yang terdiri atas beberapa komponen atau elemen-elemen, yang masing-masing menjalankan fungsinya sendiri-sendiri, dan antara satu dengan lainnya bisa saling berkonsultasi atau tidak dapat berkonsultasi. Pendekatan mekanik ini dapat diwujudkan dengan meningkatkan kuantitas dan kualitas kegiatan ekstrakurikuler bidang agama. Artinya dengan semakin menyemarakkan berbagai kegiatan ekstrakurikuler bidang agama, warga sekolah khususnya para peserta didik tidak hanya memahami PAI di kelas saja, namun juga diwujudkan dalam berbagai kegiatan ekstrakurikuler yang saling terintegrasi dengan kegiatan lainnya. Dalam pendekatan mekanik ini, khususnya bidang agama memiliki peran penting dalam pengembangan PAI untuk mewujudkan budaya religius.

Keempat, pendekatan organik, yaitu penciptaan suasana religius yang disemangati oleh adanya pandangan bahwa pendidikan agama adalah kesatuan atau sebagai sistem yang berusaha mengembangkan pandangan atau semangat hidup agamis, yang dimanifestasikan dalam sikap hidup, perilaku dan keterampilan hidup yang religius dari seluruh warga kampus. Artinya strategi pengembangan PAI dalam mewujudkan budaya religius sudah menjadi komitmen dan mendapat dukungan dari seluruh warga (Muhaimin, 2009, 305-307).

Suatu organisasi pasti tumbuh dalam lingkungan kerja tertentu. Lingkungan kerja pada dasarnya dibagi menjadi dua, yaitu lingkungan fisik berupa berbagai sarana dan prasarana yang menunjang pencapaian tujuan organisasi dan lingkungan non fisik berupa basic value atau nilai dasar yang dikembangkan pada suatu organisasi. Lingkungan kedua ini lazim disebut sebagai budaya organisasi (Bedford, 1992, 67).

Berkaitan dengan proses pembelajaran, maka iklim belajar yang kondusif antara lain dapat dikembangkan melalui berbagai 
layanan dan kegiatan sebagai berikut:

1. Menyediakan pilihan bagi peserta didik yang lambat maupun cepat dalam melakukan tugas pembelajaran. Pilihan dan pelayanan individual bagi peserta didik, terutama bagi mereka yang lambat belajar akan membangkitkan nafsu dan semangat belajar, sehingga membuat mereka betah belajar di kampus.

2. Memberikan pembelajaran remedial bagi para peserta didik yang kurang berprestasi, atau berprestasi rendah. Dalam sistem pembelajaran klasikal, sebagian peserta didik akan sulit untuk mengikuti pembelajaran secara optimal, dan menuntut peran ekstra dosen untuk memberikan pembelajaran remedial.

3. Mengembangkan organisasi kelas yang efektif, menarik, dan aman bagi perkembangan potensi seluruh peserta didik secara optimal. Termasuk dalam hal ini, adalah menyediakan bahan pembelajaran yang menarik dan menantang bagi peserta didik, serta pengelolaan kelas yang tepat, efektif, dan efisien.

4. Menciptakan kerjasama saling menghargai, baik antara peserta didik maupun antara peserta didik dengan guru dan pengelola pembelajaran lain.Hal ini mengandung implikasi bahwa setiap peserta didik memiliki kesempatan yang seluas-luasnya untuk mengemukakan pandangannya tanpa ada rasa takut mendapatkan sangsi atau dipermalukan.

5. Melibatkan peserta didik dalam proses perencanaan belajar dan pembelajaran. Dalam hal ini, dosen harus mampu memposisikan diri sebagai pembimbing dan manusia sumber. Sekali-kali, cobalah untuk melibatkan peserta didik dalam proses perencanaan pembelajaran, agar mereka merasa bertanggung jawab terhadap pembelajaran yang dilaksanakan.

6. Mengembangkan proses pembelajaran sebagai tanggung jawab bersama antara peserta didik dan dosen, sehingga dosen lebih banyak bertindak sebagai fasilisator dan sebagai sumber belajar.

7. Mengembangkan sistem evaluasi belajar dan pembelajaran yang menekankan pada evaluasi diri sendiri (self evaluation). Dalam hal ini, dosen sebagai fasilisator harus mampu membantu peserta didik untuk menilai bagaimana mereka memperoleh kemajuan dalam proses belajar yang dilaluinya (Bedford, 1992, 155-157).

\section{Dukungan/Pelibatan Komponen Pendidikan Secara Optimal}

Usaha lembaga pendidikan (kampus) dalam mewujudkan budaya religius kampus tidak akan tercapai secara optimal bila tidak didukung oleh semua komponen pendidikan seperti dosen, karyawan, mahasiswa bahkan para orangtua mahasiswa. Mereka ini dalam bahasa 
manajemen disebut sebagai pelanggan internal pendidikan (Murgatroyd, Morgan, 1993, 6). Secara lebih rinci, Sallis membagi pelanggan pendidikan menjadi dua kelompok, yaitu: internal customer (pelanggan internal) meliputi : pegawai, pelajar dan orangtua pelajar; dan external customer (pelanggan eksternal (Syafaruddin, 2002, 37).

Pelibatan secara total(total involvement), yaitu melibatkan secara total semua komponen lembaga pendidikan, baik komponen internal maupun eksternal. Tujuannya tidak lain agar mutu atau kualitas lembaga tersebut dapat ditingkatkan secara terus menerus. Proses ini merupakan bagian dari Total Quality Management (TQM) (Burhanuddin, 2002, 20).

Dalam pembahasan ini, tidak akan dijelaskan semua komponen dari pelanggan pendidikan di atas, tetapi lebih terfokus pada pelanggan internal pendidikan, yaitu dosen, pegawai, mahasiswa dan orangtua mahasiswa. Hal demikian mengingat komponen-komponen inilah yang secara langsung bersentuhan dengan proses belajar-menngajar.

Kepala kampus yang dalam hal ini berperan sebagai seorang manajer harus menerapkan perilaku yang berbeda dalam melibatkan mereka dalam aktivitas pendidikan, yaitu: Pertama, kepala kampus harus mampu menggerakkan para dosen, karyawan dan semua mahasiswa untuk berperan secara maksimal sesuai tugas dan tanggung jawabnya. George R. Terry memberikan definisi penggerakan (actuating) sebagai berikut: Actuating is setting all members of the group to want to achieve and strike to achieve the objective willingly and keeping with the managerial planning and organizing efforts. Penggerakan adalah membuat semua anggota kelompok agar mau bekerja sama dan bekerja secara ikhlas serta bergairah untuk mencapai tujuan sesuai dengan perencanaan dan usaha-usaha pengorganisasian (Hasibuan, 1984, 176-177).

Semua jenis pelanggan tersebut adalah hal penting yang harus dikenali oleh lembaga pendidikan atau pimpinan untuk kerjasama antara supervisor (penyelia) dan pelanggan pendidikan agar menghasilkan lulusan yang dapat memuaskan para pelanggan pendidikan. Agar kualitas pendidikan dapat ditingkatkan, maka diperlukan pelibatan secara optimal semua komponen tersebut.

Strategi yang dapat dilakukan untuk menggerakkan beberapa komponen tersebut antara lain:

\section{a. Motivating (memberi motivasi)}

Motivasi adalah daya dorong yang dimiliki seorang pegawai baik yang bersifat intrinsik maupun ekstrinsik yang membuatnya mau dan rela bekerja sekuat tenaga dengan mengerahkan segala 
kemampuan yang ada demi keberhasilan organisasi dalam mencapai tujuan dan sasarannya. Keberhasilan organisasi tersebut memungkinkan yang bersangkutan terpenuhi motif pribadinya berupa harapan, keinginan, cita-cita dan berbagai jenis kebutuhannya (Siagian, 2002, 40-41).

Untuk membangkitkan motivasi dosen dan karyawan, maka kepala kampus harus jeli dalam melihat setiap harapan, keinginan dan kebutuhan mereka. Seseorang yang terpenuhi kebutuhannya, maka dia akan menunjukkan komitmen kerja yang tinggi, sebaliknya seseorang yang tidak terpenuhi kebutuhannya, maka akan cenderung menunjukkan resistance (perlawanan) yang akan menghambat tercapainya tujuan lembaga.

\section{b. Developing (mengembangkan)}

Dalam mengembangkan (developing), salah satu perilaku yang sering dilakukan adalah memberi latihan (coaching) dan bimbingan (mentoring).Tujuannya adalah perubahan perilaku pegawai menuju ke arah yang lebih baik melalui pemberdayaan dengan memberikan berbagai pengetahuan dan ketrampilan yang bermanfaat dalam menjalankan pekerjaan. Prinsip yang harus diterapkan oleh pemimpin adalah bahwa perilaku pegawai dapat berubah secara bertahap, melalui pendewasaan bukan paksaan.

Beberapa perilaku yang dapat dilakukan pimpinan kampus dalam mengembangkan staf antara lain (Yukl, n.d., 104):

1) Mengidentifikasi jenis program pengembangan

2) Menjelaskan pentingnya program pengembangan

3) Memperkuat rasa percaya diri pegawai

4) Memberi cukup waktu

5) Memeriksa keberhasilan program pengembangan

6) Mendorong untuk mengaplikasikan dalam pekerjaan.

c. Supporting (memberi dukungan)

Memberi dukungan adalah perilaku kepemimpinan yang diwujudkan dalam bentuk memberi pertimbangan (consideration), penerimaan (recievement) dan perhatian (attention) terhadap kebutuhan dan keinginan para bawahan (Deep, Sussman, 1996, 17).

Adapun bentuk-bentuk dari perilaku dalam memberi dukungan yaitu:

1) Memberi perhatian dan penerimaan yang positif

2) Selalu sopan, bukan kasar dan arogan

3) Memperkuat rasa percaya diri pegawai

4) Bersedia memberi bantuan terhadap pekerjaan pegawai 
5) Bersedia membantu dalam masalah-masalah pribadi

\section{d. Recognizing (memberi pengakuan)}

Memberi pengakuan (recognizing) adalah perilaku memberi pujian dan memperlihatkan apresiasi kepada pegawai untuk mencapai kinerja yang efektif. Tujuan pemberian pengakuan ini adalah untuk memperkuat perilaku yang diinginkan serta terciptanya komitmen yang kuat terhadap keberhasilan tugas (Yukl, n.d., 109).

Adapun beberapa strategi dalam memberi pengakuan yaitu:

1) Mengakui setiap keberhasilan

2) Mengakui perbaikan-perbaikan dalam kinerja

3) Mengakui usaha pegawai meskipun gagal

4) Berilah pengakun tepat pada waktunya

5) Gunakan bentuk pengakuan yang cocok

e. Rewarding (memberi imbalan).

Memberi imbalan (rewarding) adalah kategori perilaku kepemimpinan menyangkut pemberian manfaat yang berwujud (tangible benefits) kepada pegawai. Imbalan-imbalan tersebut dapat berupa kenaikan gaji, promosi jabatan, beamahasiswa studi lanjut serta pendelegasian-pendelegasian yang mendidik.

Beberapa strategi dalam memberi imbalan yaitu (Yukl, n.d., 112):

1) Menetapkan prosedur pemberian

2) Mencari tahu imbalan apa yang menarik

3) Sesuaikan dengan standar kerja yang telah dicapai

4) Mendistribusikan imbalan dengan adil

5) Berilah imbalan pada waktu yang tepat.

\section{Budaya religius FITK UIN Maliki Malang}

Pembudayaan budaya religius di kampus merukapan hal yang sangat penting. Karena dalam membentuk manusia perlua adanya sebuah pembiasaan-pembiasaan yang baik dalam setiap prilaku manusia. Implementasi budaya religius di kampus dilakukan melalui prilaku khususnya semua civitas akademika, baik dosen maupun mahasiswa hal ini dipandang sangat perlu karena dosen adalah sebagai fasilitator dan motivator bagi mahasiswa baik dalam proses pembelajaran maupun di luar pembelajaran sehingga dosen harus mampu menjadi suri tauladan bagi mahasiswa.

Peran budaya religious dapat dilakukan melalui pembiasaan dalam berperilaku yang didasarkan pada nilai-nilai keagamaan Islam dalam segala aktivitas kesehariannya. Dalam membentuk kebiasaan kebiasaan tersebut, dapat dilakukannya sebagai berikut : pertama 
mendudukkan kampus sebagai lembaga social religious, maka perlu penciptaan kegiatan-kegiatan keagamaan Islam di lingkungan lembaga pendidikan (kampus). Kedua mengingat kampus adalah institusi yang di dalamnya terjadi hubungan melalui proses pengajaran secara professional maka diciptakan budaya religius melalui proses belajar mengajar. Penciptaan budaya religius dalam kegiatan kegiatan keseharian bisa dilakukan secara rutinitas melalui :

1) Kegiatan wajib sholat berjamaah bagi para staf dan dosen ketika jam kerja baik sholat dhuhur maupun ashar, serta anjuran untuk melakukan puasa senin-kamis.

2) Pelaksanaan khotmil qur`an setiap akhir bulan bagi para dosen dan mahasiswa.

3) Setiap awal penetapan wisudawan (yudisium) selalu diadakan do`a bersama berupa istighosah dan tahlilan.

Sedangkan penciptaan budaya religius dalam proses pembelajaran bisa dilakukan dengan membiasakan setiap jam mengajar harus dimulai dengan membaca al-fatihah kemudian dilanjutkan dengan membaca al-Qur'an bersama-sama dan setelah selesai pembelajaran ditutup dengan membaca hamdallah bersamasama. Kemudian dosen juga harus menggunakan pakaian muslim muslimah yang rapi pada jam kerja.

\section{Kesimpulan}

Penciptaan budaya religius bisa dilakukan dengan dua cara, pertama, yang bersifat vertikal dapat diwujudkan dalam bentuk meningkatkan hubungan dengan Allah swt melalui peningkatan secara kuantitas maupun kualitas kegiatan-kegiatan keagamaan yang bersifat ubudiyah, seperti: shalat berjama'ah, khatmil al-Qur'an, do'a bersama dan lain-lain. Kedua penciptaan budaya religius yang bersifat horizontal yaitu lebih mendudukkan kampus sebagai institusi sosial religius, yang jika dilihat dari struktur hubungan antar manusianya, terjadi hubungan secara profesional melalui proses pengajaran. Penciptaan budaya religious melalui proses pengajaran dapat dilakukan dengan membiasakan diri setiap jam mengajar harus dimulai dengan membaca al-fatihah kemudian dilanjutkan dengan membaca al-Qur'an bersama-sama dan setelah selesai pembelajaran ditutup dengan membaca hamdallah bersama-sama. Kemudian dosen juga harus menggunakan pakaian muslim muslimah yang rapi pada jam kerja.

Dalam mewujudkan budaya religius yang bersifat horizontal tersebut dapat dilakukan melalui hubungan sederajat atau sukarela yang didasarkan pada nilai-nilai religius, seperti: persaudaraan, 
Misbah Munir - Budaya Religius dalam Meningkatkan Profesionalisme Dosen Pendidikan Agama Islam FITK UIN Maliki Malang

kedermawanan, kejujuran, saling menghormati dan sebagainya. Pendekatan pembiasaan, keteladanan dan pendekatan persuasif atau mengajak kepada warga dengan cara yang halus, dengan memberikan alasan dan prospek baik yang bisa meyakinkan mereka. 


\section{Daftar Pustaka}

Bedford, A. D. (1992). Sistem Pengendalian Manajemen, Vol. 1. Jakarta: Bina Rupa Aksara.

Burhanuddin, dkk., (2002). Manajemen Pendidikan: Wacana, Proses dan Aplikasinya di Sekolah. Malang: UNM.

Hasibuan, M. S. P. (1984). Manajemen : Dasar, Pengertian dan Masalah. Jakarta: CV Haji Masagung.

Komariah, A., Triatna, C. (2006). Visionary Leadership Menuju Sekolah Efektif. Bandung: Bumi Aksara.

Muhaimin. (2009). Rekonstruksi Pendidikan Islam dari Paradigma Pengembangan, Manajemen Kelembagaan, Kurikulum hingga Strategi Pembelajaran. Jakarta: Raja Grafindo Persada.

Murgatroyd, S. Morgan, C. (1993) Total Quality Management at the School. USA: Open University Press .

Sam Deep, S. Sussman, L. (1996). Mengefektifkan Kinerja: Saran Untuk Mengahadapi 44 Jenis Orang yang Menimbulkan Masalah di Lingkungan Kerja. Jakarta: Midas Surya Grafindo.

Siagian, S. P. (2002). Kiat Meningkatkan Produktifitas Kerja, Jakarta: PT. Rineka Cipta.

Syafaruddin, (2002). Manajemen Mutu Terpadu dalam Pendidikan : Konsep, Strategi dan Aplikasi. Jakarta : Gramedia Widiasarana Indonesia.

Ujan, A. A. dkk. (2009). Multikulturalisme Belajar Hidup Bersama dalam Perbedaan. Jakarta: PT Indeks.

Yukl, G, (n.d,) Kepemimpinan dalam Organisasi (Leadership inOrganization). 